Article

\title{
Impact of Perovskite Composition on Film Formation Quality and Photophysical Properties for Flexible Perovskite Solar Cells
}

\author{
Guangdong $\mathrm{Li}^{1}{ }^{1}$, Xiaoping Zou ${ }^{1, *}$, Jin Cheng ${ }^{1}$, Dan Chen ${ }^{2,3}$, Yujun Yao ${ }^{1}$, \\ Chuangchuang Chang ${ }^{1}$, Xing Yu ${ }^{1}$, Zixiao Zhou ${ }^{1}$, Junqi Wang ${ }^{1}$ and Baoyu Liu ${ }^{1}$ \\ 1 Beijing Advanced Innovation Center for Materials Genome Engineering, Research Center for Sensor \\ Technology, Beijing Key Laboratory for Sensor, MOE Key Laboratory for Modern Measurement and Control \\ Technology, School of Applied Sciences, Beijing Information Science and Technology University, \\ Jianxiangqiao Campus, Beijing 100101, China; lgd1511455720@163.com (G.L.); chengjin@bistu.edu.cn (J.C.); \\ yyj10zy@gmail.com (Y.Y.); changcc037@gmail.com (C.C.); nimingyx1@163.com (X.Y.); \\ zzxfpp111@163.com (Z.Z.); 13126706081@163.com (J.W.); liubaoyu0214@163.com (B.L.) \\ 2 State Key Laboratory on Integrated Optoelectronics, Institute of Semiconductors, Chinese Academy of \\ Sciences, Beijing 100083, China; chendan1988@semi.ac.cn \\ 3 Center of Materials Science and Optoelectronics Engineering, University of Chinese Academy of Sciences, \\ Beijing 100049, China \\ * Correspondence: xpzou2014@163.com; Tel.: +86-1364-105-6404
}

Academic Editors: Federico Bella and Shijing Sun

Received: 22 January 2020; Accepted: 4 February 2020; Published: 7 February 2020

\begin{abstract}
In recent years, flexible perovskite solar cells have drawn tremendous attention in the field of wearable devices, and optimization of perovskite composition plays an important role in improving film quality and photophysical properties. At present, some researchers have only studied A-site organic cations mixing or $\mathrm{X}$-site halide anions mixing in the $\mathrm{ABX}_{3}$ structure of perovskite, but there are few reports on co-mixing of A-site and X-site ions in flexible perovskite solar cells. In this paper, we mainly try to study the effects of different concentrations of mixed formamidine methylamine halide $\left(\mathrm{FA}_{\mathrm{x}} \mathrm{MA}_{1-\mathrm{x}} \mathrm{Br}_{\mathrm{x}} \mathrm{Cl}_{\mathrm{y}} \mathrm{I}_{1-\mathrm{x}-\mathrm{y}}\right)$ precursor solutions on the quality and photophysical properties of perovskite films under low temperature process. We conclude that the film quality and photophysical properties reached the best results when the optimized precursor solution concentration was 60:6:6. The investigation on composition optimization in this experiment laid the foundation for the improvement of the performance of flexible perovskite solar cells. We also use the results of this experiment to prepare flexible perovskite solar cells based on carbon electrodes, which are expected to be applied in other flexible optoelectronic or electro-optical devices.
\end{abstract}

Keywords: perovskite composition; film quality; photophysical properties; flexible perovskite solar cells

\section{Introduction}

Flexible perovskite solar cells are expected to be integrated into wearable mobile devices to form self-powered devices due to their light weight, flexibility, and low cost, which has aroused increasing interest in the field of organic-inorganic hybrid perovskite solar cells [1-5]. Recently, the power conversion efficiency (PCE) of flexible perovskite solar cells has rocketed from the initial $6 \%$ to $18.4 \%[6,7]$.

There are many factors that affect the quality and photophysical properties of perovskite films. For example, the different composition of the perovskite functional layer will change the quality and photophysical properties of the perovskite film. The concentration of the precursor solution 
has a greater effect on the morphology of the perovskite layer, which affects the efficiency of the device [8-10]. In 2017, Wang et al. prepared flexible perovskite solar cells by mixing $\mathrm{CH}_{3} \mathrm{NH}_{3}{ }^{+}\left(\mathrm{MA}^{+}\right)$ and $\mathrm{HN}=\mathrm{CHNH}_{3}{ }^{+}\left(\mathrm{FA}^{+}\right)$, extending the absorption edge of perovskite to longer wavelength, enhancing photocurrent of the flexible perovskite solar cells, and significantly improving the performance of the device [11]. In 2018, Du et al. prepared flexible perovskite solar cell with a PCE of $13.27 \%$ by mixing $\mathrm{I}^{-}$and $\mathrm{Cl}^{-}$in perovskite, and adding suitable $\mathrm{H}_{2} \mathrm{O}$ additive to the perovskite precursor solution, improving film quality [12].

However, when $\mathrm{FA}^{+}$and $\mathrm{MA}^{+}$are mixed in the perovskite, grains become much smaller, leading to relatively high grain boundary density, which may cause charge recombination [11]. Therefore, in our study, $\mathrm{PC}_{61} \mathrm{BM}$ was used to passivate the grain boundaries of perovskite film, increase the grain size, and improve device performance [11,13].

$\mathrm{FA}^{+}$has the advantages of changing the lattice parameters of perovskite and reducing the perovskite band gap, and the thermal stability of solar cells can also be improved when $\mathrm{FA}^{+}$and $\mathrm{MA}^{+}$are mixed [11,14]; $\mathrm{Cl}^{-}$and $\mathrm{Br}^{-}$improve the crystallinity and coverage of the films [15]. In recent years, for flexible perovskite solar cells, there have been a few reports on the mixing of organic cations or halide anions in perovskite layers [11,12], but there have been few reports on the co-mixing of organic cations and halide anions. Therefore, based on the above advantages, different from previous studies, this experiment was oriented to flexible perovskite solar cells. We prepared mixed $\left.\mathrm{HC}\left(\mathrm{NH}_{2}\right)_{2}\right)_{x}\left(\mathrm{CH}_{3} \mathrm{NH}_{3}\right)_{1-\mathrm{x}} \mathrm{PbBr}_{\mathrm{x}} \mathrm{Cl}_{\mathrm{y}} \mathrm{I}_{3-\mathrm{x}-\mathrm{y}} / \mathrm{FA}_{\mathrm{x}} \mathrm{MA}_{1-\mathrm{x}} \mathrm{PbBr}_{\mathrm{x}} \mathrm{Cl}_{\mathrm{y}} \mathrm{I}_{3-\mathrm{x}-\mathrm{y}}$ perovskite by using $\mathrm{FA}^{+}$and $\mathrm{MA}^{+}$to achieve the A-site mixing in the typical $\mathrm{ABX}_{3}$ structure of perovskite and by using $\mathrm{I}^{-}, \mathrm{Cl}^{-}$, and $\mathrm{Br}^{-}$to achieve $X$-site mixing. By changing the concentration of the mixed formamidine methylamine halide $\left(\mathrm{FA}_{\mathrm{x}} \mathrm{MA}_{1-\mathrm{x}} \mathrm{Br}_{\mathrm{x}} \mathrm{Cl}_{\mathrm{y}} \mathrm{I}_{1-\mathrm{x}-\mathrm{y}}\right)$ precursor solution, we prepared perovskite solar cells under low temperature process and characterized the perovskite film and device performance. We have also obtained an optimal ratio of precursor solution, which also has laid the foundation for the flexible perovskite solar cell preparation and optimization process; we then used the results of this experimental study to prepare flexible perovskite solar cells based on carbon film counter electrodes.

In this experiment, we prepared perovskite layers by adjusting the concentrations of mixed formamidine methylamine halide $\left(\mathrm{FA}_{\mathrm{x}} \mathrm{MA}_{1-\mathrm{x}} \mathrm{Br}_{\mathrm{x}} \mathrm{Cl}_{\mathrm{y}} \mathrm{I}_{1-\mathrm{x}-\mathrm{y}}\right)$ precursor solution, and then prepared the perovskite solar cell. Through the characterization of the perovskite film and device performance, we found that when the concentration was 60:6:6, the film quality, photophysical properties, and device performance reached the best result.

\section{Results and Discussion}

In this paper, we mainly investigated the effects of different concentrations of mixed formamidine methylamine halide $\left(\mathrm{FA}_{\mathrm{x}} \mathrm{MA}_{1-\mathrm{x}} \mathrm{Br}_{\mathrm{x}} \mathrm{Cl}_{\mathrm{y}} \mathrm{I}_{1-\mathrm{x}-\mathrm{y}}\right)$ precursor solution on perovskite film quality and photophysical properties under a low temperature process. SEM images of perovskite layers prepared with different concentrations of $\mathrm{FA}_{x} \mathrm{MA}_{1-\mathrm{x}} \mathrm{Br}_{\mathrm{x}} \mathrm{Cl}_{\mathrm{y}} \mathrm{I}_{1-\mathrm{x}-\mathrm{y}}$ precursor solutions are shown in Figure 1. Figure 1 are SEM images of perovskite layers prepared at concentrations of precursor solutions of 40:4:4, 50:5:5, 60:6:6, and 70:7:7, respectively, at a magnification of 20,000 times.

It can be seen from Figure $1 \mathrm{a}$ that when the concentration of $\mathrm{FA}_{\mathrm{x}} \mathrm{MA}_{1-\mathrm{x}} \mathrm{Br}_{\mathrm{x}} \mathrm{Cl}_{\mathrm{y}} \mathrm{I}_{1-\mathrm{x}-\mathrm{y}}$ precursor solution was 40:4:4, the size of the perovskite grain was small, and the shape was irregular. As seen in Figure 1b, when the concentration of the solution was 50:5:5, the grain size of perovskite increased, and the grain boundary was clearer, but there were traces of scale growth on the surface of the grains. When the concentration of the solution was increased to 60:6:6, compared with Figure 1a,b as shown in Figure 1c, the diameter of the perovskite grains reached the maximum value, and the largest grain diameter even exceeded $1 \mu \mathrm{m}$. The film surface was flat, the shape was regular15, the grain boundaries were clear, and there were no obvious defects; thus, the film quality was better. As seen in Figure 1d, when the concentration of the solution continued to increase to 70:7:7, obvious pinholes appeared on the surface of the film, the grain boundary became blurred, and the film surface became rough, which may have been caused by the abnormal growth of perovskite [16]. Based on the above analysis, we 
drew the conclusion that the quality of perovskite thin film first got better and then worse with the increase of the concentration of mixed $\mathrm{FA}_{\mathrm{x}} \mathrm{MA}_{1-\mathrm{x}} \mathrm{Br}_{\mathrm{x}} \mathrm{Cl}_{\mathrm{y}} \mathrm{I}_{1-\mathrm{x}-\mathrm{y}}$ precursor solution. The film quality was best when the precursor solution concentration was 60:6:6.

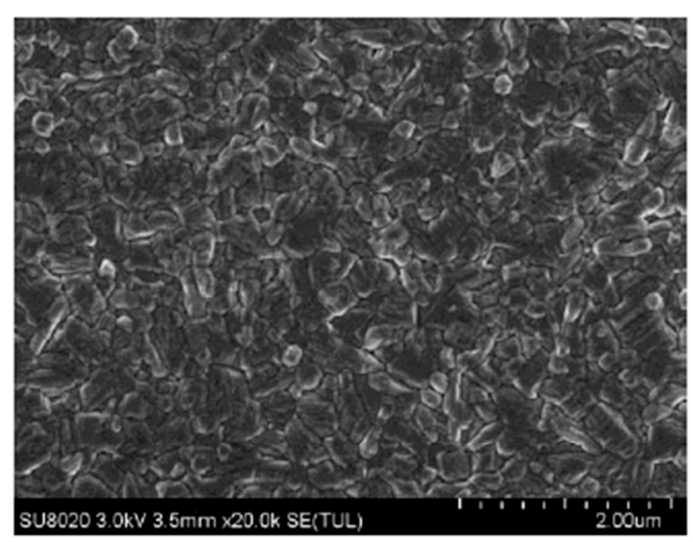

(a)

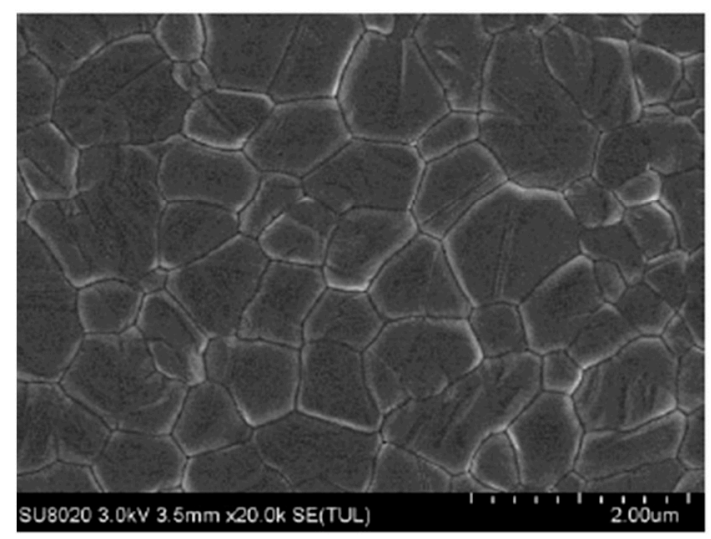

(c)

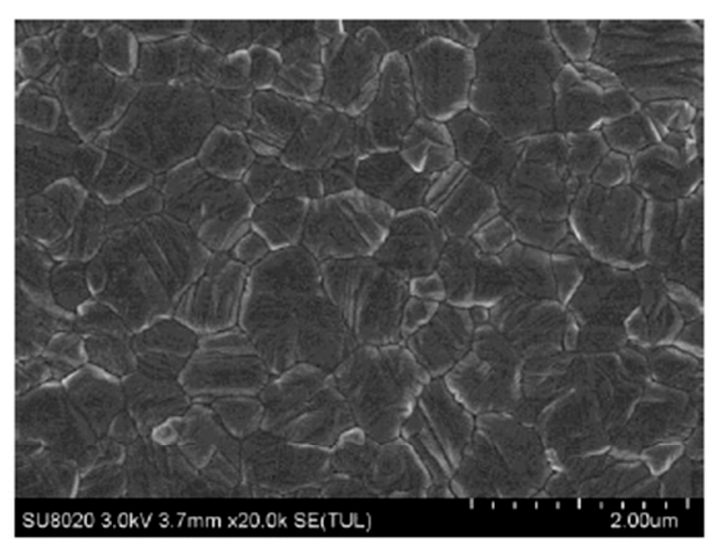

(b)

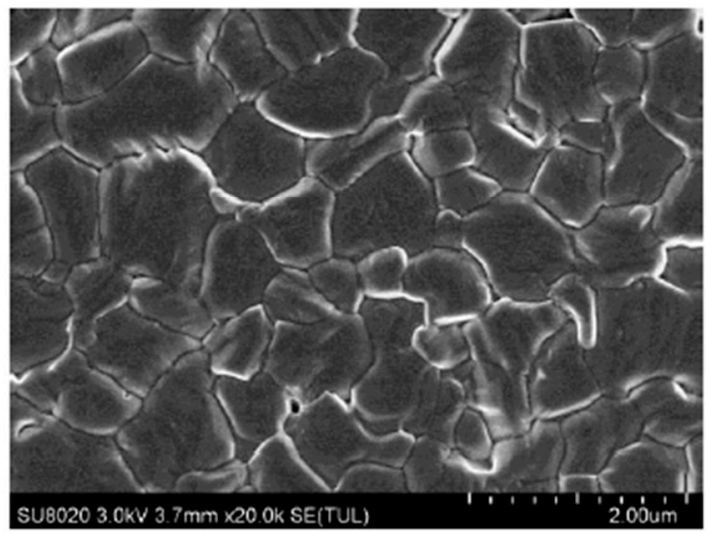

(d)

Figure 1. SEM images of perovskite layer prepared with formamidine methylamine halide precursors solutions with concentrations of 40:4:4 (a), 50:5:5 (b), 60:6:6 (c), and 70:7:7 (d), respectively.

Figure 2 shows the normalized XRD patterns of perovskite layer prepared with $\mathrm{FA}_{\mathrm{x}} \mathrm{MA}_{1-\mathrm{x}} \mathrm{Br}_{\mathrm{x}} \mathrm{Cl}_{\mathrm{y}} \mathrm{I}_{1-\mathrm{x}-\mathrm{y}}$ precursor solution of different concentrations. The peak at $2 \theta$ at $12.5^{\circ}$ was the characteristic peak of $\mathrm{PbI}_{2}$. The diffraction peaks at $14.0^{\circ}$ and $28.1^{\circ}$ corresponded to the (111) and (222) planes of the perovskite, and the diffraction peak at $31.6^{\circ}$ was the (123) plane of the perovskite crystals [17]. It was found that when the concentration of the precursor solution was 40:4:4, the ratio of the $\mathrm{PbI}_{2}$ emission peak $\left(12.5^{\circ}\right)$ to the perovskite emission peak $\left(14.0^{\circ}\right)$ was greater than 2 , which indicated the ratio of the two precursor solutions mixed to form perovskite was very low. As the solution concentration increased, the emission peak of $\mathrm{PbI}_{2}$ gradually decreased, which means that more $\mathrm{PbI}_{2}$ was involved in the chemical reaction to form perovskite $[9,11]$. When the solution concentration was 60:6:6, there was a slight $\mathrm{PbI}_{2}$ residue in the crystal, which would be beneficial to passivate the grain boundary of perovskite film and improve carrier life $[18,19]$. The ratio of the intensity of the $28.1^{\circ}$ diffraction peak to the $31.6^{\circ}$ diffraction peak at this concentration was higher than that a concentration of 70:7:7, indicating that the preferential orientation axis of the perovskite crystals prepared at a concentration of 60:6:6 was along the (111) axis, and the film had a more pure crystal phase [17], which is consistent with Figure 1c. 


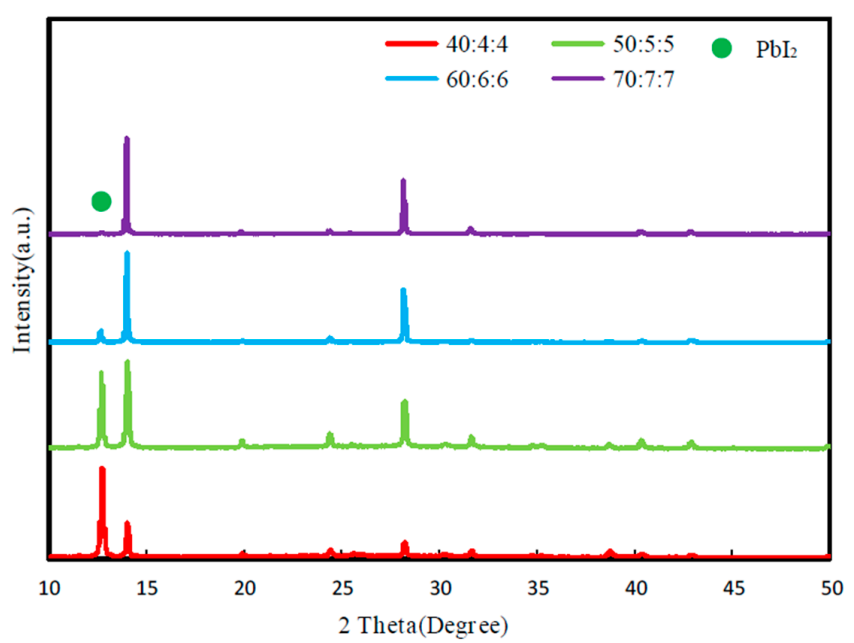

Figure 2. Normalized XRD patterns of perovskite layers prepared with mixed formamidine methylamine halide precursor solutions at different concentrations.

The UV-vis absorption spectrum of the perovskite layer prepared with $\mathrm{FA}_{\mathrm{x}} \mathrm{MA}_{1-\mathrm{x}} \mathrm{Br}_{\mathrm{x}} \mathrm{Cl}_{\mathrm{y}} \mathrm{I}_{1-\mathrm{x}-\mathrm{y}}$ precursor solution of different concentrations is shown in Figure 3, and the curve accorded with the light absorption characteristics of conventional perovskite films. When the concentration of $\mathrm{FA}_{\mathrm{x}} \mathrm{MA}_{1-\mathrm{x}} \mathrm{Br}_{\mathrm{x}} \mathrm{Cl}_{\mathrm{y}} \mathrm{I}_{1-\mathrm{x}-\mathrm{y}}$ precursor solution was 40:4:4, the UV-vis absorption spectrum of the prepared perovskite layer is shown in the red line in the figure. The absorbance of the prepared perovskite film at this concentration was lower than that at the other three concentrations, which was ascribed to the poor morphology of the film. With the increasing of concentration, the light absorption intensity increased gradually. When the precursor solution concentration was 60:6:6 and 70:7:7, the prepared perovskite films had high absorbance due to the good crystallinity of the perovskite films [20]. The perovskite film with the concentration of 40:4:4 exhibited the rough absorption edge at $801 \mathrm{~nm}$; the perovskite film with the concentration of 50:5:5 exhibited the rough absorption edge at $805 \mathrm{~nm}$; the perovskite film with the concentration of 70:7:7 exhibited the rough absorption edge at $808 \mathrm{~nm}$; the absorption wavelength of the perovskite film prepared at the concentration of 60:6:6 was about $810 \mathrm{~nm}$, which indicated that the band gap of the perovskite prepared at this concentration was narrower, which was more conducive to the generation of electron-holes after absorbing photons, improving the short-circuit current density, and thus improving the PCE of the solar cell [9].

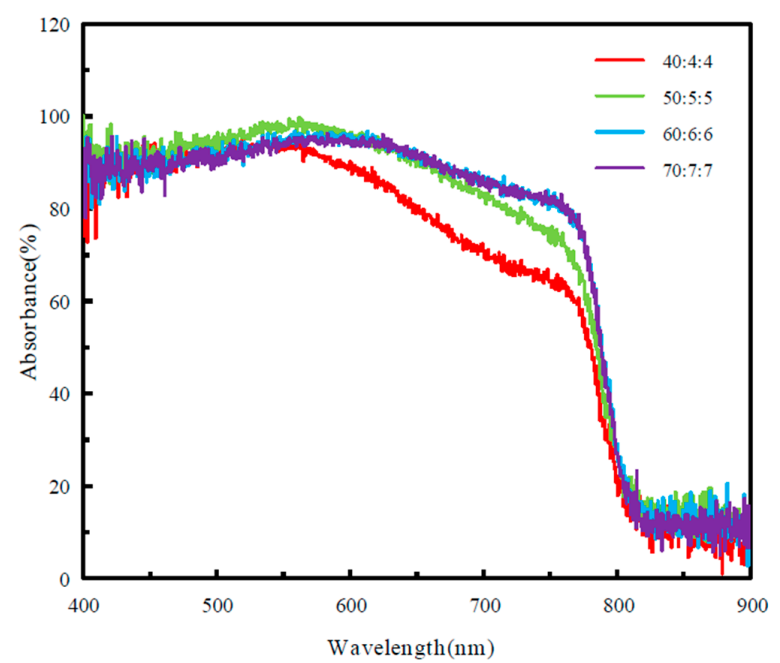

Figure 3. UV-vis absorption spectra of perovskite layers prepared with different concentrations of formamidine methylamine halide precursor solutions. 
Figure 4 shows the photoluminescence spectroscopy of perovskite layers prepared by $\mathrm{FA}_{\mathrm{x}} \mathrm{MA}_{1-\mathrm{x}} \mathrm{Br}_{\mathrm{x}} \mathrm{Cl}_{\mathrm{y}} \mathrm{I}_{1-\mathrm{x}-\mathrm{y}}$ precursor solution of different concentrations. It can be seen that when the concentrations of mixed $\mathrm{FA}_{\mathrm{x}} \mathrm{MA}_{1-\mathrm{x}} \mathrm{Br}_{\mathrm{x}} \mathrm{Cl}_{\mathrm{y}} \mathrm{I}_{1-\mathrm{x}-\mathrm{y}}$ precursor solution was 50:5:5 and 60:6:6, the photoluminescence peak of the film was relatively low. This is because the two films had better film morphology, fewer defects, and lower probability of radiation recombination [12], which is also consistent with the results of the SEM diagram.

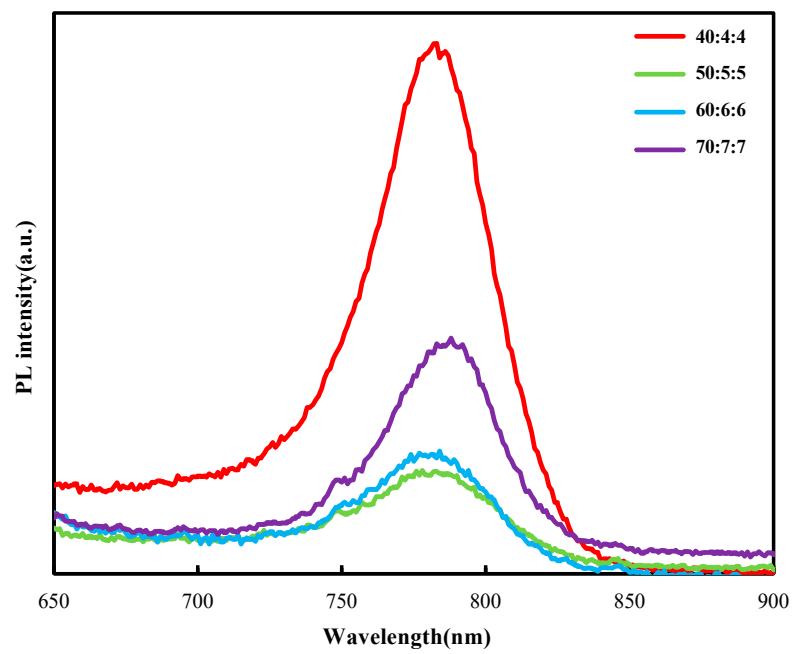

Figure 4. Photoluminescence spectroscopy of perovskite layers prepared with different concentrations of formamidine methylamine halide precursors solutions.

The device structure prepared on the indium tin oxide (ITO) conductive substrate in this experiment is shown in Figure 5a; the structures are ITO/Low-temperature (LT)- $\mathrm{TiO}_{2} / \mathrm{PC}_{61} \mathrm{BM} / \mathrm{FA}_{\mathrm{x}} \mathrm{MA}_{1-\mathrm{x}} \mathrm{PbBr}_{\mathrm{x}} \mathrm{Cl}_{\mathrm{y}} \mathrm{I}_{3-\mathrm{x}-\mathrm{y}} /$ Spiro/Carbon/Fluorine-doped tin oxide (FTO), respectively. When sunlight enters from the conductive substrate, it passes through the electron transport layer to the perovskite layer prepared by $\mathrm{FA}_{\mathrm{x}} \mathrm{MA}_{1-\mathrm{x}} \mathrm{Br}_{\mathrm{x}} \mathrm{Cl}_{\mathrm{y}} \mathrm{I}_{1-\mathrm{x}-\mathrm{y}}$ precursor solution of different concentrations, and then passes through the hole transport layer to the electrode made of carbon film. When the device is connected to the external circuit, a current is generated.

(a)

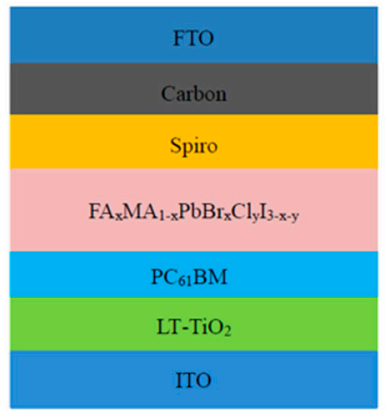

Sunlight

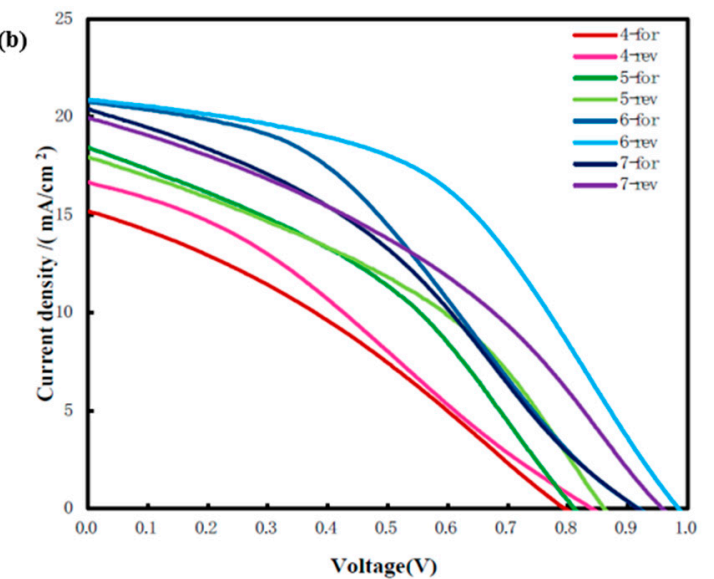

Voltage(V)

Figure 5. (a) Device structure diagram; (b) J-V curves of perovskite solar cells prepared with different concentrations of formamidine methylamine halide precursor solution on ITO substrate.

The J-V curves of perovskite solar cells prepared by $\mathrm{FA}_{\mathrm{x}} \mathrm{MA}_{1-\mathrm{x}} \mathrm{Br}_{\mathrm{x}} \mathrm{Cl}_{\mathrm{y}} \mathrm{I}_{1-\mathrm{x}-\mathrm{y}}$ precursor solution of different concentrations are shown in Figure $5 b$, and the performance parameters of corresponding curves in Figure 5b are shown in Table 1. In the definition diagram, 4-for represents FAI:MABr:MACl 
= $40 \mathrm{mg}: 4 \mathrm{mg}: 4 \mathrm{mg}$ and forward scanning of the device, and 4-rev represents the reverse scanning. As the concentration of the mixed $\mathrm{FA}_{\mathrm{x}} \mathrm{MA}_{1-\mathrm{x}} \mathrm{Br}_{\mathrm{x}} \mathrm{Cl}_{\mathrm{y}} \mathrm{I}_{1-\mathrm{x}-\mathrm{y}}$ in precursor solution continued to increase, the PCE of the device increased first and then decreased. The best concentration was FAI:MABr:MACl $=60 \mathrm{mg}: 6 \mathrm{mg}: 6 \mathrm{mg}$, which was consistent with the corresponding parameters of the J-V curves, giving a $\mathrm{V}_{\mathrm{oc}}$ of $0.98 \mathrm{~V}$, a J $\mathrm{sc}_{\mathrm{sc}}$ of $20.87 \mathrm{~mA} / \mathrm{cm}^{2}$, an FF of $47.68 \%$, and a PCE of $9.79 \%$. This may have resulted from the proper mass ratio of the two precursor solutions and the complete solute reaction.

Table 1. Performance parameters of perovskite solar cells prepared with different concentrations of formamidine methylamine halide precursor solution.

\begin{tabular}{ccccc}
\hline Samples & PCE (\%) ${ }^{\mathbf{a}}$ & $\mathbf{V}_{\mathbf{o c}}(\mathbf{V})^{\mathbf{b}}$ & $\mathbf{J}_{\mathbf{s c}}\left(\mathbf{m A} / \mathbf{c m}^{2}\right)^{\mathbf{c}}$ & FF (\%) $^{\mathbf{d}}$ \\
\hline 4-for & 3.87 & 0.79 & 15.18 & 32.08 \\
\hline 4-rev & 4.28 & 0.84 & 16.66 & 30.56 \\
\hline 5-for & 5.70 & 0.81 & 18.43 & 38.10 \\
\hline 5-rev & 6.02 & 0.86 & 17.96 & 38.96 \\
\hline 6-for & 7.28 & 0.92 & 20.78 & 38.19 \\
\hline 6-rev & 9.79 & 0.98 & 20.87 & 47.68 \\
\hline 7-for & 6.64 & 0.91 & 20.39 & 35.57 \\
\hline 7-rev & 7.12 & 0.96 & 19.94 & 37.28 \\
\hline
\end{tabular}

a Power conversion efficiency; ${ }^{\mathrm{b}}$ Open-circuit voltage; ${ }^{\mathrm{c}}$ Short-circuit photocurrent density; ${ }^{\mathrm{d}}$ Fill factor.

According to the results of the experiments discussed above, we prepared flexible perovskite solar cells on flexible ITO/polyethylene naphthalate (PEN) substrate by using the mixed $\mathrm{FA}_{\mathrm{x}} \mathrm{MA}_{1-\mathrm{x}} \mathrm{Br}_{\mathrm{x}} \mathrm{Cl}_{\mathrm{y}} \mathrm{I}_{1-\mathrm{x}-\mathrm{y}}$ precursor solution with a concentration of 60:6:6, and realized a reverse scanning PCE of $3.24 \%$. Figure 6 shows the J-V curve of the flexible perovskite solar cell, Table 2 shows the performance parameters of the corresponding curve in Figure 6, and Figure 7 shows the photo of the flexible solar cell. In the experiment, the carbon film counter electrode was used as the solar cell photocathode and was prepared by candle flame fumigation. Due to the instability of the candle flame and the uncertainty of the fumigation time, the performance of the solar cell was greatly affected. In addition, the overall optimization of the device and the interface modification of each layer were not been completed. Later, more efforts will be made to explore better processes to improve the efficiency of flexible perovskite solar cells.

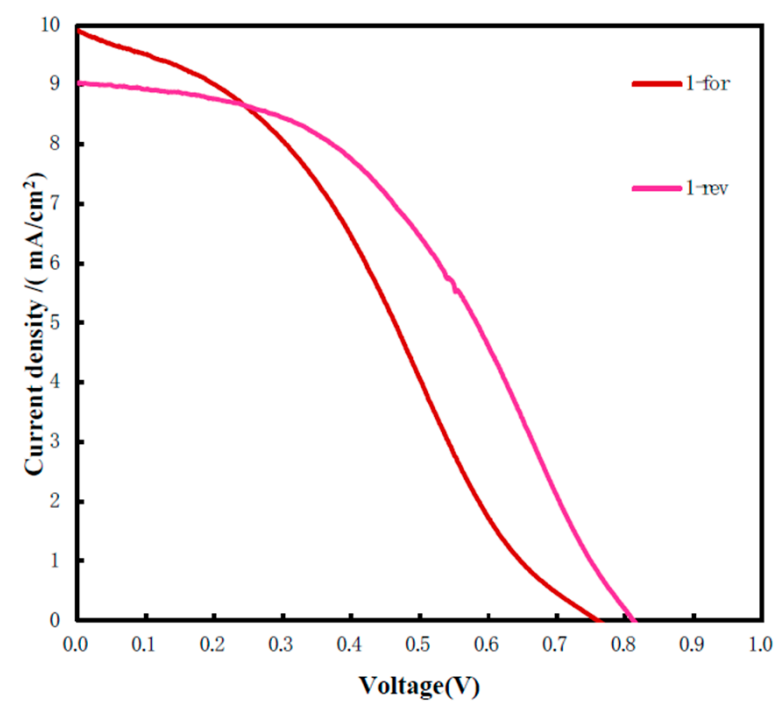

Figure 6. J-V curve of flexible perovskite solar cell. 
Table 2. Performance parameters of flexible perovskite solar cell.

\begin{tabular}{ccccc}
\hline Samples & PCE (\%) ${ }^{\mathbf{a}}$ & $\mathbf{V}_{\mathbf{~ o c}}(\mathbf{V})^{\mathbf{b}}$ & $\mathbf{J}_{\mathbf{s c}}\left(\mathbf{m A} / \mathbf{c m}^{2}\right)^{\mathbf{c}}$ & FF (\%) $^{\mathbf{d}}$ \\
\hline 1-for & 2.60 & 0.76 & 9.92 & 34.52 \\
\hline 1-rev & 3.24 & 0.81 & 9.04 & 44.23 \\
\hline
\end{tabular}

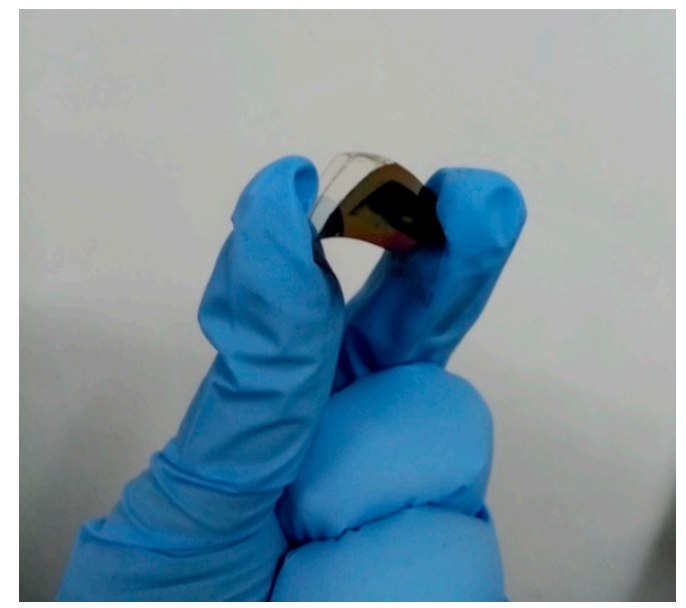

Figure 7. Flexible perovskite solar cell based on carbon electrode.

\section{Materials and Experimental Methods}

\subsection{Materials}

FTO substrate (thickness of $2.2 \mathrm{~mm}$, surface resistance of $15 \Omega / \mathrm{sq}$, transmittance of more than $85 \%$ ) and ITO rigid substrate (thickness of $1.1 \mathrm{~mm}$, surface resistance of $7 \Omega / \mathrm{sq}$, about $85 \%$ light transmittance) were purchased from Shanghai Mater Win New Materials Co., Ltd. (Shanghai, China). Flexible ITO/PEN substrate (area resistance of about $15 \Omega / \mathrm{sq}$ ) was purchased from Aoge Technology Co., Ltd. Low temperature nanocrystalline $\mathrm{TiO}_{2}$ spin coating solution $\left(\mathrm{LT}-\mathrm{TiO}_{2}\right)$, chlorobenzene $\left(\mathrm{C}_{6} \mathrm{H}_{5} \mathrm{Cl}\right)$ (purity $\geq 99 \%$ ), dimethyl sulfoxide (DMSO) (purity $\geq 99.8 \%$ ), and $N, N$-dimethylformamide (DMF) (purity $\geq 99.8 \%$ ) were also purchased from Shanghai Mater Win New Materials Co., Ltd. (Shanghai, China). Formamidine iodine $\left(\mathrm{HC}\left(\mathrm{NH}_{2}\right)_{2} \mathrm{I}\right)$ (purity $\left.\geq 99 \%\right)$, methylamine bromide $\left(\mathrm{CH}_{3} \mathrm{NH}_{3} \mathrm{Br}\right)$ (purity $\geq 99 \%$ ), methylamine chloride $\left(\mathrm{CH}_{3} \mathrm{NH}_{3} \mathrm{Cl}\right)$ (purity $\geq 99 \%$ ), lead iodide $\left(\mathrm{PbI}_{2}\right)$ (purity $\geq 99.99 \%$ ), [6,6]-phenyl $\mathrm{C}_{61}$ methyl butyrate $\left(\mathrm{PC}_{61} \mathrm{BM}\right)$ (purity $\geq 99 \%$ ), and Spiro-OMeTAD were also purchased from Xi'an Polymer Light Technology Corp. (Xi'an, China).

\subsection{Device Fabrication}

The cleanliness of FTO/ITO/flexible ITO/PEN transparent conductive substrate has a very important impact on the performance of perovskite solar cells, so it must be cleaned. First, after cutting the conductive substrate and putting it into a clean petri dish, we added an appropriate amount of deionized water and detergent and placed it in an ultrasonic vibration washing machine for ultrasonic cleaning for $20 \mathrm{~min}$. Next, we added an appropriate amount of absolute ethanol to the petri dish and ultrasonically cleaned it for $20 \mathrm{~min}$. Then, an appropriate amount of a mixed solution of isopropanol, acetone, and deionized water was added to the petri dish, the volume ratio of which was 1:1:1, and it was ultrasonically washed for $20 \mathrm{~min}$. Finally, the cleaned conductive substrate was dried at a constant temperature in a drying box for $90 \mathrm{~min}$, and then placed in a UV light washer for $15 \mathrm{~min}$ [21].

The low temperature dense $\mathrm{TiO}_{2}$ layer was prepared by spin-coating low temperature nanocrystalline $\mathrm{TiO}_{2}$ spin coating solution on an ITO conductive substrate under a low temperature process. Only one layer was spin-coated at a spin-coating speed of $2000 \mathrm{rpm}$ and a time of $30 \mathrm{~s}$. First, 
spin-coated ITO conductive substrate was left at room temperature for $1 \mathrm{~h}$, then placed on a hot plate at room temperature to heat the hot plate program to $150^{\circ} \mathrm{C}$ with a heating rate of $8{ }^{\circ} \mathrm{C} / \mathrm{min}$, and finally at $150{ }^{\circ} \mathrm{C}$ for $20 \mathrm{~min}$. The $\mathrm{PC}_{61} \mathrm{BM}$ electron transport layer was prepared by dissolving $\mathrm{PC}_{61} \mathrm{BM}$ in chlorobenzene and configuring it into $\mathrm{PC}_{61} \mathrm{BM}$ solution with a concentration of $20 \mathrm{mg} / \mathrm{mL}$, and then spin-coating the solution on a low temperature dense $\mathrm{TiO}_{2}$ layer at a spin-coating speed of $1500 \mathrm{rpm}$ and a time of $30 \mathrm{~s}$.

The perovskite layer was prepared by dissolving $\mathrm{PbI}_{2}$ in a mixed solution of $\mathrm{N}, \mathrm{N}$-dimethylformamide (DMF) and dimethyl sulfoxide (DMSO) (the volume ratio of DMF to DMSO was $0.95: 0.05$ ) to form $600 \mathrm{mg} / \mathrm{mL}$ of precursor solution. Then the mass ratios of FAI, MABr, and MACl of $40 \mathrm{mg}: 4 \mathrm{mg}: 4 \mathrm{mg} ; 50 \mathrm{mg}: 5 \mathrm{mg}: 5 \mathrm{mg} ; 60 \mathrm{mg}: 6 \mathrm{mg}: 6 \mathrm{mg}$; and $70 \mathrm{mg}: 7 \mathrm{mg}: 7 \mathrm{mg}$, respectively, were dissolved in $1 \mathrm{~mL}$ of anhydrous isopropanol to prepare mixed solutions of different concentrations. Then, the mass ratios of FAI, MABr, and MACl, which were $40 \mathrm{mg}: 4 \mathrm{mg}: 4 \mathrm{mg}$; $50 \mathrm{mg}: 5 \mathrm{mg}: 5 \mathrm{mg}$; $60 \mathrm{mg}: 6 \mathrm{mg}: 6 \mathrm{mg}$; and $70 \mathrm{mg}: 7 \mathrm{mg}: 7 \mathrm{mg}$, respectively, were dissolved in $1 \mathrm{~mL}$ of anhydrous isopropanol to form 4 different concentrations of formamidine methylamine halide $\left(\mathrm{FA}_{\mathrm{x}} \mathrm{MA}_{1-\mathrm{x}} \mathrm{Br}_{\mathrm{x}} \mathrm{Cl}_{\mathrm{y}} \mathrm{I}_{1-\mathrm{x}-\mathrm{y}}\right)$ precursor solutions. Next, the $\mathrm{PbI}_{2}$ precursor solution was directly spin-coated on the electron-transporting layer of $\mathrm{PC}_{61} \mathrm{BM}$; the spin-coating speed was $1500 \mathrm{rpm}$, and the spin-coating time was $30 \mathrm{~s}$. After the rotation was stopped, the mixed methylformamide methylamine halide $\left(\mathrm{FAxMA}_{1-\mathrm{x}} \mathrm{Br}_{\mathrm{x}} \mathrm{ClyI}_{1-\mathrm{x}-\mathrm{y}}\right)$ precursor solution with different concentrations was evenly drip-coated on the unheated $\mathrm{PbI}_{2}$ film using a pipette and then spin-coated immediately with a spin-coating speed of $1500 \mathrm{rpm}$; the spin coating time was $30 \mathrm{~s}$. Finally, the spin-coated substrate was immediately placed on a glue dryer and heated at $150{ }^{\circ} \mathrm{C}$ for $20 \mathrm{~min}$. In this way, perovskite film was made.

The hole-transporting layer was spin-coated on a perovskite film with Spiro-OMeTAD solution at a speed of $3000 \mathrm{rpm}$ for $30 \mathrm{~s}$ [22]. Finally, the conductive surface of the cleaned FTO conductive glass substrate was cleaned with a candle flame to make a carbon film counter electrode. The carbon film was aligned on the top of the device, and the two sides were clamped with clips to complete the device preparation [23].

\subsection{Characterization}

A field emission scanning electron microscope (SEM) (SIGMA, Zeiss, Jena, Germany) was used to characterize the perovskite film. An XRD spectrum was obtained using an X-ray diffractometer (D8 Focus, Bruker, Dresden, Germany) from a perovskite film deposited on ITO/LT- $\mathrm{TiO}_{2} / \mathrm{PC}_{61} \mathrm{BM}$. The absorption spectra of perovskite films were obtained by an ultraviolet (UV) visible absorption spectrometer (Avantes, Apeldoorn, the Netherlands), and the photoemission spectra (PL spectra) of perovskite films were measured by a fluorescence spectrometer (HORIBA Jobin Yvon, Paris, France). Finally, a solar simulator (Sol 3A, Oriel, New port, RI, USA) was used to measure the current-voltage $(\mathrm{J}-\mathrm{V})$ characteristic curve of the solar cell under standard AM 1.5 G light.

\section{Conclusions}

In summary, our work shows that the optimization of the perovskite composition can improve the film quality and photophysical properties. The SEM image shows that when the solution concentration is $60: 6: 6$, the quality of the perovskite film reaches the best result. From the UV-vis absorption spectrum, it can be seen that when the solution concentration is $60: 6: 6$, the absorbance of the film is better, and the absorption edge also reaches $810 \mathrm{~nm}$, which is more conducive to improving the short-circuit current density. It can be seen from the PL spectrum that with the solution concentration increasing, the photoluminescence peak decreases first and then increases. When the solution concentration is 50:5:5 and 60:6:6, the photoluminescence peaks of the film are very low, which is more conducive for the carrier to be injected from the perovskite layer into the $\mathrm{TiO}_{2}$ layer. Finally, according to the J-V curve, it can be seen that when the solution concentration is $60: 6: 6$, the device efficiency reaches the highest level. 
The study of perovskite composition optimization in this experiment paves the way for the exploration of co-mixing processes in flexible perovskite solar cells, which is also expected to be used in other flexible photosensitive devices or light emitting diodes. The flexible perovskite solar cell based on a carbon electrode as a photocathode is also shown, and flexible perovskite solar cells based on a gold electrode as a photocathode are under investigation.

Author Contributions: G.L. wrote the paper. D.C. designed the experiments. G.L., Z.Z. and J.C. analyzed the data. Y.Y. and C.C. prepared the samples. X.Y., B.L. and J.W. performed all the measurements. X.Z. supervised the project. All authors commented and approved the paper. All authors have read and agreed to the published version of the manuscript.

Funding: This research was funded by the project of the Natural Science Foundation of China (no. 61875186), the project of the Natural Science Foundation of Beijing (no. Z160002), the Key Research Projects of BISTU (2019-22, 2019-23, and 2019-27), and the Beijing Key Laboratory for Sensors of BISTU (no. 2019CGKF007).

Acknowledgments: Authors thank Yifei Wang, Xiaotong Li and Xiaolan Wang for helpful English grammar checking.

Conflicts of Interest: The authors declare no conflict of interest.

\section{References}

1. Wang, X.; Li, Z.; Xu, W.; Kulkarni, S.A.; Batabyal, S.K.; Zhang, S.; Cao, A.; Wong, L.H. TiO 2 nanotube arrays based flexible perovskite solar cells with transparent carbon nanotube electrode. Nano Energy. 2015, 11, 728-735. [CrossRef]

2. Kaltenbrunner, M.; Adam, G.; Głowacki, E.D.; Drack, M.; Schwödiauer, R.; Leonat, L.; Apaydin, D.H.; Groiss, H.; Scharber, M.C.; White, M.S.; et al. Flexible high power-per-weight perovskite solar cells with chromium oxide-metal contacts for improved stability in air. Nat. Mater. 2015, 14, 1032-1039. [CrossRef]

3. Di Giacomo, F.; Fakharuddin, A.; Jose, R.; Brown, T.M. Progress, challenges and perspectives in flexible perovskite solar cells. Energy Environ. Sci. 2016, 9, 3007-3035. [CrossRef]

4. Luo, Q.; Ma, H.; Hou, Q.; Li, Y.; Ren, J.; Dai, X.; Yao, Z.; Zhou, Y.; Xiang, L.; Du, H.; et al. All-Carbon-Electrode-Based Endurable Flexible Perovskite Solar Cells. Adv. Funct. Mater. 2018, 28, 1706777. [CrossRef]

5. Li, Y.; Xu, G.; Cui, C.; Li, Y. Flexible and Semitransparent Organic Solar Cells. Adv. Energy Mater. 2017, 8, 1701791. [CrossRef]

6. Docampo, P.; Ball, J.M.; Darwich, M.; Eperon, G.E.; Snaith, H.J. Efficient organometal trihalide perovskite planar-heterojunction solar cells on flexible polymer substrates. Nat. Commun. 2013, 4, 2761. [CrossRef] [PubMed]

7. $\quad$ Feng, J.; Zhu, X.; Yang, Z.; Zhang, X.; Niu, J.; Wang, Z.; Zuo, S.; Priya, S.; Liu, S.F.; Yang, D. Record Efficiency Stable Flexible Perovskite Solar Cell Using Effective Additive Assistant Strategy. Adv. Mater. 2018, 30, 1801418. [CrossRef] [PubMed]

8. Jeon, N.J.; Noh, J.H.; Yang, W.S.; Kim, Y.C.; Ryu, S.; Seo, J.; Seok, S.I. Compositional engineering of perovskite materials for high-performance solar cells. Nature 2015, 517, 476-480. [CrossRef] [PubMed]

9. Bi, C.; Chen, B.; Wei, H.; DeLuca, S.; Huang, J. Efficient Flexible Solar Cell based on Composition-Tailored Hybrid Perovskite. Adv. Mater. 2017, 29, 1605900. [CrossRef]

10. Zhao, Y.; Zhu, K. Efficient Planar Perovskite Solar Cells Based on $1.8 \mathrm{eV}$ Band Gap $\mathrm{CH}_{3} \mathrm{NH}_{3} \mathrm{PbI}_{2}$ Br Nanosheets via Thermal Decomposition. J. Am. Chem. Soc. 2014, 136, 12241-12244. [CrossRef]

11. Wang, C.; Zhao, D.; Yu, Y.; Shrestha, N.; Grice, C.R.; Liao, W.; Cimaroli, A.J.; Chen, J.; Ellingson, R.J.; Zhao, X.; et al. Compositional and morphological engineering of mixed cation perovskite films for highly efficient planar and flexible solar cells with reduced hysteresis. Nano Energy. 2017, 35, 223-232. [CrossRef]

12. Du, Y.; Cai, H.; Bao, X.; Xing, Z.; Wu, Y.; Xu, J.; Huang, L.; Ni, J.; Li, J.; Zhang, J. Flexible Perovskite Solar Cells onto Plastic Substrate Exceeding 13\% Efficiency Owing to the Optimization of $\mathrm{CH}_{3} \mathrm{NH}_{3} \mathrm{PbI}_{3-\mathrm{x}} \mathrm{Cl}_{\mathrm{x}}$ Film via $\mathrm{H}_{2} \mathrm{O}$ Additive. Acs Sustain. Chem. Eng. 2017, 6, 1083-1090. [CrossRef]

13. Ameen, S.; Akhtar, M.S.; Seo, H.-K.; Shin, H.-S. Towards design of metal oxide free perovskite solar cell paradigm: Materials processing and enhanced device performance. Chem. Eng. J. 2015, 281, 599-605. [CrossRef] 
14. Yu, Y.; Wang, C.; Grice, C.R.; Shrestha, N.; Chen, J.; Zhao, D.; Liao, W.; Cimaroli, A.J.; Roland, P.J.; Ellingson, R.J.; et al. Improving the Performance of Formamidinium and Cesium Lead Triiodide Perovskite Solar Cells using Lead Thiocyanate Additives. Chemsuschem 2016, 9, 3288-3297. [CrossRef]

15. Xue, Q.; Hu, Z.; Sun, C.; Chen, Z.; Huang, F.; Yip, H.-L.; Cao, Y. Metallohalide perovskite-polymer composite film for hybrid planar heterojunction solar cells. RSC Adv. 2015, 5, 775-783. [CrossRef]

16. Bäurer, M.; Shih, S.-J.; Bishop, C.; Harmer, M.; Cockayne, D.; Hoffmann, M. Abnormal grain growth in undoped strontium and barium titanate. Acta Mater. 2010, 58, 290-300. [CrossRef]

17. Yang, W.S.; Park, B.-W.; Jung, E.H.; Jeon, N.J.; Kim, Y.C.; Lee, D.U.; Shin, S.S.; Seo, J.; Kim, E.K.; Noh, J.H.; et al. Iodide management in formamidinium-lead-halide-based perovskite layers for efficient solar cells. Science 2017, 356, 1376-1379. [CrossRef]

18. Chen, Q.; Zhou, H.; Song, T.-B.; Luo, S.; Hong, Z.; Duan, H.-S.; Dou, L.; Liu, Y.; Yang, Y. Controllable self-induced passivation of hybrid lead iodide perovskites toward high performance solar cells. Nano Lett. 2014, 14, 4158-4163. [CrossRef]

19. Colella, S.; Mosconi, E.; Fedeli, P.; Listorti, A.; Gazza, F.; Orlandi, F.; Ferro, P.; Besagni, T.; Rizzo, A.; Calestani, G.; et al. $\mathrm{MAPbI}_{3-\mathrm{x}} \mathrm{Cl}_{\mathrm{x}}$ Mixed Halide Perovskite for Hybrid Solar Cells: The Role of Chloride as Dopant on the Transport and Structural Properties. Chem. Mater. 2013, 25, 4613-4618. [CrossRef]

20. Wang, D.; Chang, Y.; Pang, S.; Cui, G. The effect of grain orientation on the morphological stability of the organic-inorganic perovskite films under elevated temperature. J. Semicond. 2017, 38, 14002. [CrossRef]

21. Malviya, K.D.; Dotan, H.; Yoon, K.R.; Kim, I.-D.; Rothschild, A. Rigorous substrate cleaning process for reproducible thin film hematite $\left(\alpha-\mathrm{Fe}_{2} \mathrm{O}_{3}\right)$ photoanodes. J. Mater. Res. 2015, 31, 1565-1573. [CrossRef]

22. Ling, T.; Zou, X.; Cheng, J.; Bai, X.; Ren, H.; Chen, D. Modified Sequential Deposition Route through Localized-Liquid-Liquid-Diffusion for Improved Perovskite Multi-Crystalline Thin Films with Micrometer-Scaled Grains for Solar Cells. Nanomaterials 2018, 8, 416. [CrossRef] [PubMed]

23. Zhang, N.; Guo, Y.; Yin, X.; He, M.; Zou, X. Spongy carbon film deposited on a separated substrate as counter electrode for perovskite-based solar cell. Mater. Lett. 2016, 182, 248-252. [CrossRef]

Sample Availability: The data used to support the findings of this study are available from the corresponding author upon request.

(C) 2020 by the authors. Licensee MDPI, Basel, Switzerland. This article is an open access article distributed under the terms and conditions of the Creative Commons Attribution (CC BY) license (http://creativecommons.org/licenses/by/4.0/). 